\title{
CAUSES OF THE DIEBACK OF LITTORAL STANDS IN AN OVERPOPULATED WATER BIRD RESERVE: ROLE OF EUTROPHICATION, FISH AND GEESE
}

\author{
RICHARD SVIDENSKÝ ${ }^{1}$, ANDREA KUČEROVÁ², \\ and HANA ČİŽKOVÁ3,*
}

\author{
${ }^{1}$ Faculty of Agriculture, University of South Bohemia, Studentská 13, CZ-37005 České Budějovice, Czech Republic, \\ ORCID: 0000-0001-9837-2467 \\ ${ }^{2}$ Institute of Botany, Academy of Sciences of the Czech Republic, Dukelská 135, CZ-37901 Třeboň, Czech Republic, \\ ORCID: 0000-0001-7729-1596 \\ ${ }^{3}$ Faculty of Agriculture, University of South Bohemia, Studentská 13, CZ-37005 České Budějovice, Czech Republic, \\ ORCID: 0000-0001-8692-3903 \\ * Corresponding author: hcizkova@zf.jcu.cz
}

\begin{abstract}
European fishponds can serve as refuges for water birds if the fish stocks are limited, but the effects of other ecological factors on their ecological stability are rarely considered. The aim of this study is to determine the causes of marked dieback of littoral stands dominated by Typha angustifolia L. in a hypertrophic fishpond that is also a valuable water bird reserve. A field study and two experiments were conducted in order to separate the effects of mineral nutrient availability, redox conditions, fish and water birds. The physico-chemical characteristics of the water and sediments confirmed hypertrophic conditions in the fishpond, but a mesocosm experiment did not indicate it had a negative effect on plant growth. On the other hand, a field enclosure experiment showed that in sparse stands, unfenced parts had a significantly smaller shoot density than fenced parts. This was attributed to grazing by greylag geese (Anser anser L.). In addition, damage to belowground parts of plants were ascribed to large individuals of albeit a few large common carp (Cyprinus carpio L.). This study highlights a conservation dilemma as large numbers of geese destroy littoral stands in fishpond nature reserves, which then become unsuitable nesting sites for other species of water birds.
\end{abstract}

Keywords: carp; fishpond; grazing damage; nature reserve; sediment; Typha angustifolia

\section{Introduction}

European fishponds are important refuges of aquatic and wetland organisms in intensively used agricultural landscapes (IUCN 1997). They are man-made shallow water bodies of various sizes, with an area ranging from several hundred square meters to more than $1 \mathrm{~km}^{2}$. Many fishponds have well developed littoral plants, which provide breeding sites for water birds, including rare species such as the great crested grebe (Podiceps cristatus L.), grey heron (Ardea cinerea L.), greater white-fronted goose (Anser albifrons Scopoli) and great bittern Botaurus stellaris L.) (e.g. Švažas and Stanevičius 1998; Janda and Ševčík 2002; Polak 2007; Gergely et al. 2009; Nieoczym 2010; Flis and Gwiazda 2018). Large fishponds, which have an area greater than $1 \mathrm{~km}^{2}$, also serve water birds as staging areas during migration and wintering grounds (Miklín and Macháček 2016). European fishponds are important for maintaining the biodiversity of water birds and are nature reserves, which are protected areas according to the EU Directive No. 2009/147/EC (Birds Directive) or Wetlands of International Importance according to the Ramsar Convention (Bird Life International 2001).

Although European fishponds resemble natural shallow lakes in many aspects, their ecology is largely determined by the rearing of fish, mainly cyprinids (Kestemont 1995; Pechar 2000; Schlumberger and Girard 2013). Fish production is promoted by manuring, liming and feeding the fish, which in turn increase nutrient availability in the water column and promote the accumulation of nutrient rich organic sediments at the bottom (Baxa et al. 2019). Large stocks of fish control the food chains in the water and at the bottom by feeding on large zooplankton and benthos. This results in steep vertical gradients in oxygen content, $\mathrm{pH}$, chlorophyll content and light penetration in summer (Bíró 1995; Potužák et al. 2007; Weber and Brown 2009).

In addition to open water, dense littoral stands of plants, such as the common reed (Phragmites australis [Trin. Exd Steud.]) and cattails (Typha spp.), provide habitats for many species of water birds, especially ducks. They use them as shelter, source of material for building nests and also feed on these plants and/or the large populations of invertebrates and fish fry that inhabit the littoral stands. On the other hand, some species can destroy these stands if they are abundant. This is documented both for birds (Bakker et al. 2018) and fish (Crivelli 1983). In addition, the size and stability of the littoral stands can be reduced by many other factors such as floods, high water levels (Ostendorp 1989), eutrophication (van der Putten 1997; Čižková et al. 1999), toxic substances in the sediment (Armstrong et al. 1996; Armstrong and Armstrong 2001) and, finally, mechanical damage caused by human activities.

All of the injurious effects listed above can occur in fishponds and many of them are closely related to fishpond management (Hejný et al. 2002; Francová et al. 2019a). In spite of the importance of both open water 
and littoral stands of plants for water birds, most ecosystem studies focus on only one of these two components. There are several studies assessing the relationship between fishpond management and biodiversity (Broyer and Calenge 2010; Broyer and Curtet 2012; Francová et al. 2019b), but they do not specifically deal with the stability of the littoral stands of plants. In addition, studies on the factors affecting the dynamics of littoral stands of plants are almost exclusively on Phragmites australis (e.g. Ostendorp 1989; van der Putten 1997; Armstrong and Armstrong 2001), while knowledge on that of other common species, including Typha spp., is scarce.

In order to resolve this, an ecosystem study was undertaken of a hypertrophic fishpond and valuable water bird reserve, in which the littoral stands of mainly Typha angustifolia L. markedly declined both in area and shoot density between 2004 and 2013. This study started in 2013 and ended in 2016, and had the following specific aims:

1. to document the extent of the decline in the area of the littoral stand of plants that occurred between 2004 and 2013 and determine the condition of the remaining stands in terms of their horizontal pattern and plant morphology;

2. to assess the physic-chemical characteristic of the water and sediments as possible determinants of the condition of the different $T$. angustifolia stands: dense (compact), sparse (declining) and absent;

3. to assess the potential toxicity of the fishpond sediment on plant growth and root morphology in a mesocosm:

4. to determine whether particular animals are destroying the littoral stands of plants using enclosures.

\section{Materials and Methods}

\section{Site description}

The ecosystem studied was the Bažina fishpond $(49.0092322 \mathrm{~N}, 14.4393331 \mathrm{E})$, which is part of a valuable water bird reserve, Vrbenské rybníky (Vrbenské fishponds), near the city of České Budějovice in the Czech

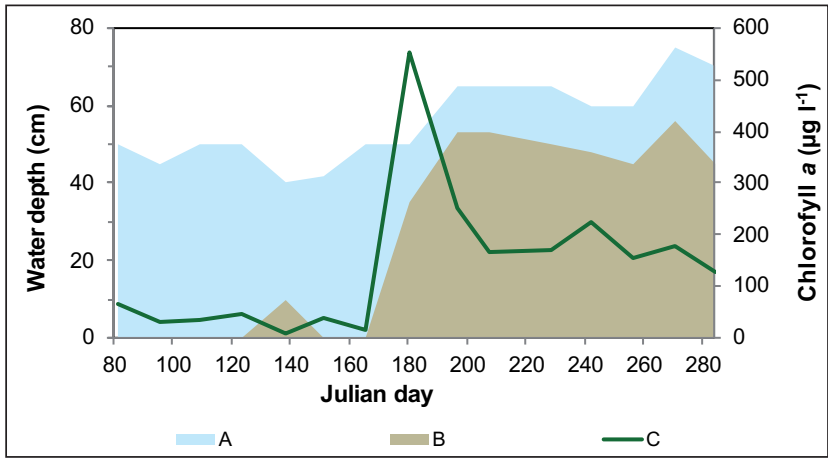

Fig. 1 Seasonal changes in water transparency and chlorophyll $a$ content at different depths. The dashed vertical lines separate spring from summer (Julian day 173) and summer from autumn (Julian dan 267), respectively. A - photic zone; B - dark zone; C - chlorophyll a content.
Republic. The Vrbenské rybníky is a system of shallow water bodies (mean depth 1-2 m) used for rearing fish, mainly the common carp (Cyprinus carpio L.), which makes up about $90 \%$ of the fish community. Because of its importance as a bird habitat, the area has been a nature reserve since 1990, a special area of conservation according to Directive 92/43/EEC since 2005 and a part of an Important area for Birds, Českobudějovické rybníky, according to EU Directive 2009/147/ES since 2009. The Bažina fishpond ( $6.13 \mathrm{ha}$ ) is of special conservation value because various species of duck, e.g. great crested grebe (Podiceps cristatus L.) and red-necked grebe (Podiceps grisegena Boddaert), nest in its littoral plant stands (Albrecht 2003). The fishpond is also an important gathering site for greylag geese (Anser anser L.) prior to their winter migration.

Bažina fishpond is hypertrophic and the water is turbid and there are no submerged macrophytes. From 2013 to 2016 the water in spring was clear and the photic zone extended down to the bottom and oxygen content was near $100 \%$ saturation in the whole water column. When the mean temperature of the water column increased above $20{ }^{\circ} \mathrm{C}$ in late spring (usually at the end of May), a marked vertical stratification developed (Fig. 1).
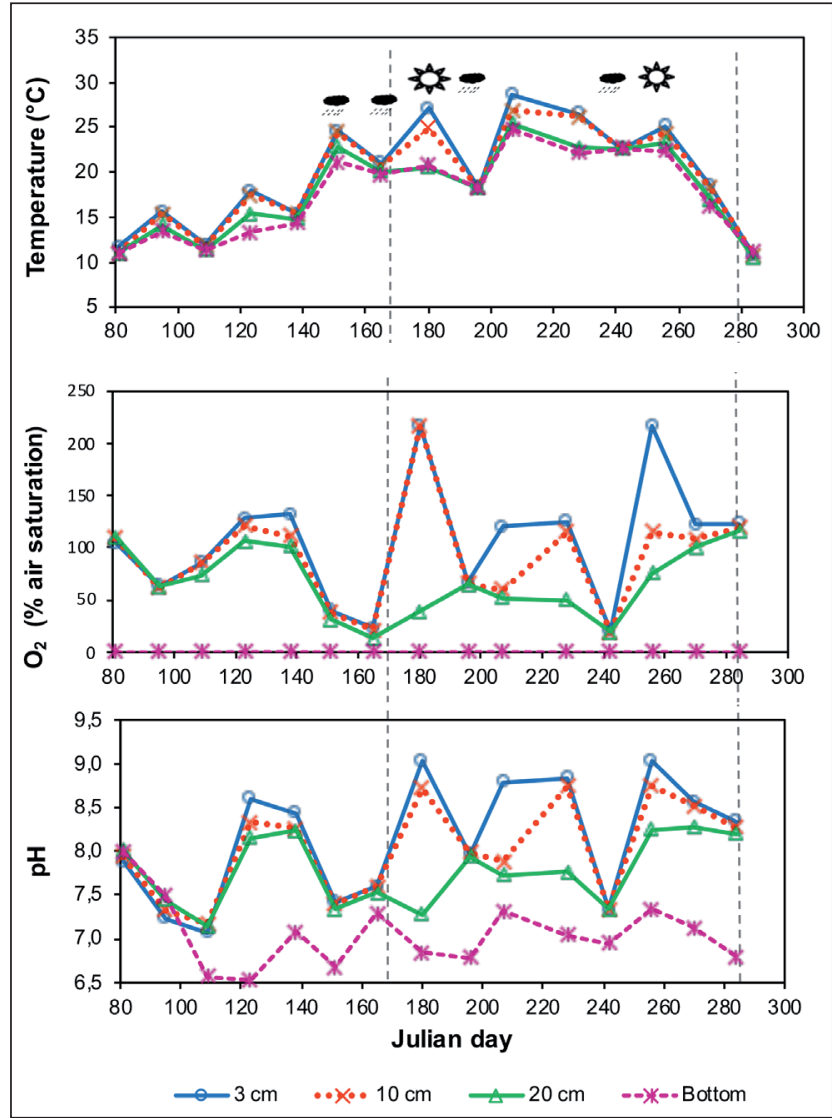

Fig. 2 Seasonal changes in the physico-chemical features of the water column. Vertical dashed lines separate spring from summer (Julian day 173) and summer from autumn (Julian day 267). The legend indicates the depths at which measurements were recorded. Values for $30 \mathrm{~cm}$ are very similar to those for $20 \mathrm{~cm}$ so only the latter is shown. Symbols of a cloud and a sun represent rainy and sunny weather, respectively, on the days sampled. 
The photic zone decreased to less than $0.2 \mathrm{~m}$ (Fig. 2). This was associated with a strong peak in chlorophyll $a$ content, reaching a seasonal maximum of over $500 \mathrm{ug} \mathrm{l}^{-1}$, an extremely high value even for hypertrophic fishponds in the same geographic region (cf. Šimek et al. 2019). The vertical stratification was most pronounced in sunny weather, when the oxygen content in the water column was more than $200 \%$ air saturation near the surface and hypoxic below a depth of $20 \mathrm{~cm}$ (Fig. 2).

The extent of the hypoxic zone corresponded with the depth of loose sediment. On rainy days, the water column was hypoxic up to the water surface due to the mixing action of rain (Fig. 3). The bottom was always anoxic. The pattern in $\mathrm{pH}$ values was similar to that of oxygen content. Near the water surface, it fluctuated between 9.0 on sunny days and 7.3 on rainy days, whereas at the bottom it ranged from 7.3 to 6.5. In autumn the oxygen content and $\mathrm{pH}$ levels were similar to those recorded in spring, but water transparency remained low (Fig. 1).

The fishpond was used mainly for rearing carp fry or one-year-old fingerlings. In the years preceding this study (i.e. from 2004 to 2011) and also in 2015 and 2016, it was stocked every spring with a total biomass of up to $50 \mathrm{~kg} \mathrm{ha}^{-1}$, which is ten times less than the usual stock in production fishponds. The fish was harvested every year during a draw-down in October or November. The draw-down lasted for about one week. In 2012-2014, the fishpond was not stocked. This was because in autumn

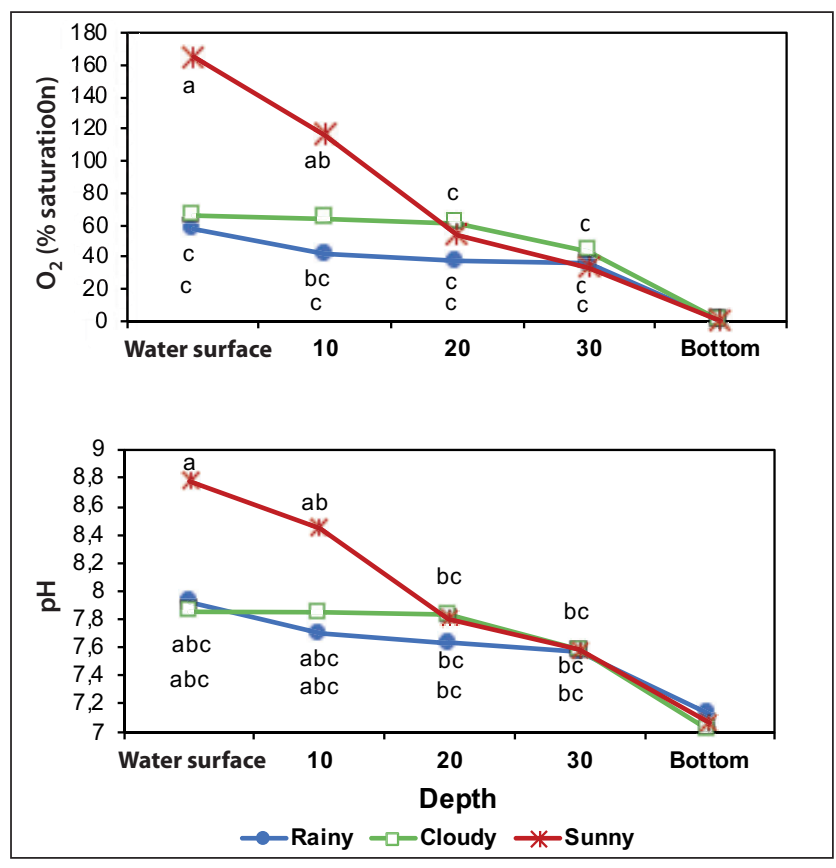

Fig. 3 Changes in oxygen content and pH with depth in Bažina fishpond when the mean water temperatures were $\geq 20^{\circ} \mathrm{C}$. Different lines and symbols indicate rainy, cloudy and sunny weather, respectively. Different small letters denote significant differences for a particular type of weather, based on repeated measures ANOVA followed by post-hoc Tukey tests. Bottom values were not included in the analysis because of extremely low variance. For original data see Fig. 2.
2011, some adult carp (about $2 \mathrm{~kg}$ ) arrived in Bažina from an upstream fishpond. Their total weight in spring 2012 was estimated to be less than $50 \mathrm{~kg} \mathrm{ha}^{-1}$, which corresponds to the biomass of fish stocked in other years. These carp were successively harvested in the autumns of 2012-2014. No supplementary food was added for the fish and the fishpond was not limed at least from 2002, (i.e. before the die-back of littoral stands was first noticed). The mean seasonal height of the water column was about $0.5 \mathrm{~m}$ with the summer minimum of $0.4 \mathrm{~m}$ occurring usually in July.

\section{Assessment of littoral vegetation}

A vegetation map was made in 2013 in order to document the past and current area of the littoral stands. Background information included a local topographic map and orthophotographs of the area from 2004 (i.e. before the die-back of the littoral stands was first observed in 2013. In August 2013 borders of vegetation units were recorded in the field using an Ashtech GPS Magellan mobile mapper 10. Five vegetation units were defined: (1) Phragmites australis dominated stands, (2) sparse (cover $\leq 35 \%)$ and (3) dense (>35\%) stands dominated by Typha angustifolia, and (4) sparse (cover $\leq 35 \%)$ and (5) dense $(>35 \%)$ dominated by T. latifolia. After the fishpond was drained in October 2013 (in order to harvest the fish), remnants of the dead stands were identified on the fishpond bottom and also recorded. The data were further processed using ArcGIS ESRI 10 in order to create the map and assess the area of particular vegetation units.

A preliminary investigation of plant condition was carried out in August 2013. It focused on signs of damage to plants (uprooting of clumps, the intensity of grazing damage and the proportion of living and dead shoots or leaves in clumps). Three $0.5 \mathrm{~m}$ diameter clumps that were only loosely connected to the bottom were dug up in order to determine the incidence of dead roots and rhizomes. In addition, the presence of horizontal rhizomes, ensuring vegetative expansion, was recorded in a $0.1 \mathrm{~m}$ thick surface layer of the sediment in close vicinity of ten shoots growing in sparse stands. Subsequently, a photographic documentation of the current condition of the littoral stands was taken at two-week intervals throughout the study.

\section{Survey of water and sediment characteristics}

Basic physico-chemical parameters were investigated in 2013 in areas formerly or currently overgrown with T. angustifolia L.; we distinguished three types of biotope (1) dense (compact) stands of T. angustifolia, (2) sparse stands of T. angustifolia and (3) open water in the area where T. angustifolia was formerly present (dead stands). In all three biotopes, the vertical profile consisted of three layers: (1) aquatic photic zone consisting of clear water determined using a Secchi disk, (2) dark zone of sludge consisting of water and fine loose sediment and (3) solid bottom sediment. In order to keep the vertical stratifica- 
tion intact, all in situ measurements and sampling were performed from a boat.

Two sampling sites were established in each type of biotope and investigated at the time of the seasonal maximum aboveground biomass (13 August 2013). Prior to the sampling, the depths of the photic and dark zones were measured. Water conductivity and $\mathrm{pH}$ were recorded in the middle of the photic zone using a portable meter WTW Multi 3430 set D. Water samples were taken from the photic zone using a $0.4 \mathrm{~m}$ long plexiglass tube of $0.05 \mathrm{~m}$ internal diameter. Two replicate samples of water were collected at each site. Loose sediment was sampled within the dark zone in the same manner. The volume of these samples was approximately 1 litre. The solid bottom sediment was sampled using a PVC tube with an $0.1 \mathrm{~m}$ internal diameter. The samples were stored in a refrigerator overnight and analysed as described below. There were three replicates of each sediment sample.

Alkalinity of the water was determined by sample titration with hydrochloric acid to $\mathrm{pH}$ 4.5. The content of chlorophyll $a$ was estimated immediately after sampling with a fluorometer Aquafluor 8000-001 (Turner Designs, Canada) using a standard procedure. The concentrations of total $\mathrm{N}$, total $\mathrm{P}, \mathrm{K}, \mathrm{Ca}$ and $\mathrm{Mg}$ were determined for samples of fishpond water and water in the loose sediment, which was obtained by centrifugation of the loose sediment followed by filtration of the supernatant. Total nitrogen concentration was determined using a modified Kjeldahl method (ISO 11261) by mineralization to ammonium ion. Total phosphorus concentration was estimated according to Kopáček and Hejzlar (1995) as phosphate ion after mineralization in perchloric acid. Ammonium and phosphate ions were estimated calorimetrically in a flow-through Flow Injection Analyzer Lachat QC 8500 (Lachat Instruments, USA) using standard protocols. The concentrations of cations $(\mathrm{Ca}, \mathrm{Mg}, \mathrm{K})$ were determined by ion chromatography using 881 Compact IC Pro-Cation (Metrohm AG, Switzerland).

Air-dried samples of the fine loose sediment and the bottom sediment, respectively, were used for analysis of main mineral nutrients. The concentrations of cations $(\mathrm{Ca}, \mathrm{Mg}$, and $\mathrm{K}$ ) were determined in soil solution obtained using the Mehlich II extraction method (Zbíral 1995; Zbíral and Němec 2002) and atomic absorption spectroscopy (spectrometer contrAA, Analytik Jena AG, DE). Total phosphorus and nitrogen were estimated after mineralization of ground samples using the same method as in the case of water samples. The content of organic matter in the sediments was based on the loss on ignition at $550{ }^{\circ} \mathrm{C}$ in a muffle furnace for 4 hours. The results were expressed per unit dry mass obtained by drying partial samples of sediment at $105^{\circ} \mathrm{C}$.

Redox potential (Eh) was investigated in situ in 2013 at the same sites where water and sediments were sampled for chemical analyses. We used two approaches: a preliminary survey and a quantitative estimate. The prelim- inary survey was based on the colour change from reddish to dark grey associated with the reduction of ferric to ferrous iron $\left(\mathrm{Fe}^{\mathrm{III}} \rightarrow \mathrm{Fe}^{\mathrm{II}}\right.$ ) (Mitsch and Gosselink 2015). In August 2013, iron sticks with an oxidized reddish layer on their surface were placed at the same sites used for sampling sediment. Altogether, 18 sticks of $0.5 \mathrm{~m}$ in length were inserted to a $10 \mathrm{~cm}$ depth in the solid bottom sediment, their upper parts extended through the layer of the fine loose sediment into clear water. In November 2013, the sticks were checked for the presence of the grey colour. The quantitative measurements of the redox potential were taken at the same sites on 13 August 2013. Eh was estimated as the electric potential between a Pt electrode installed at the surface of the solid sediment and an $\mathrm{Ag} / \mathrm{AgCl}(3 \mathrm{M} \mathrm{KCl})$ reference electrode immersed in the water. The reference electrode had a potential of $210 \mathrm{mV}$ against the standard hydrogen electrode (Friis et al. 1998).

\section{Mesocosm}

In 2014, a mesocosm was set up in order to determine whether anaerobic fishpond sediment affects the growth of the roots of Typha angustifolia and/or causes injury to them. There were two treatments, which differed in the type of the rooting substrate: (1) anaerobic sediment taken from the bottom of Bažina fishpond and (2) washed river sand. The latter was used as a control substrate in which there was negligible microbial activity. The sand was enriched with a slow-dissolving fertilizer Osmocote in order to compensate for the lack of mineral nutrients necessary for plant growth.

The plants were propagated from seeds collected at the Bažina fishpond. Twenty-four plants of similar size were selected for the experiment. They had one shoot with 3-4 leaves with a total length of $1.94 \pm 0.40 \mathrm{~m}$ (mean \pm standard deviation, $\mathrm{n}=24$ ). The initial biomass was determined for five additional plants, which were separated into shoots, rhizomes and roots and their dry weight recorded after drying at $85^{\circ} \mathrm{C}$ to constant weight. The resulting dry mass of shoots, rhizomes and roots were $15.1 \pm 8.4,9.1 \pm 5.1 \mathrm{~g}$ and $2.8 \pm 1.9 \mathrm{~g}$, respectively (mean \pm standard deviation, $\mathrm{n}=5$ ).

Each of the 24 plants selected was planted in a 32-liter basket-type container. Twelve baskets were filled with the fishpond sediment, which contained $1584 \mathrm{mg}$ total $\mathrm{N}$, $238 \mathrm{mg}$ total $\mathrm{P}, 67 \mathrm{mg} \mathrm{K}$ and $139 \mathrm{mg} \mathrm{Mg}$ per 1 litre. The other twelve baskets were filled with the washed river sand supplemented with 6 g Osmocote per litre, which contained $900 \mathrm{mg}$ total N, $600 \mathrm{mg}$ total P, $720 \mathrm{mg} \mathrm{K}$ and $1200 \mathrm{mg} \mathrm{Mg}$. An iron stick was inserted in each basket as an indication of the redox potential (in the same manner as in the survey of the fishpond sediment characteristics, see above). Baskets with the same type of substrate were randomly distributed between two fibre-glass tubs and all filled with substrate to the same height. In summary, there were two types of substrate, each placed in two tubs and a total of four tubs. Each tub contained six plants 
with a total of 24 plants in the four tubes. The tubs were kept outside and water was added to the tubs to keep the water level at about $0.1 \mathrm{~m}$ above the surface of the substrate. Algal growth was prevented by a $0.05 \mathrm{~m}$ thick layer of perlite on the water surface.

The experiment lasted from 30 July to 20 October 2014. At the end of the experiment, the plants were harvested and the following characteristics were determined: number of shoots, number and length of live and dead leaves, respectively, and also the biomass of shoots, rhizomes and roots after drying to constant weight at $85^{\circ} \mathrm{C}$.

\section{Enclosures}

In 2015, enclosures were established in stands of littoral plants in order to assess the effect of mechanical damage by waterfowl and fish on shoot density. Four pairs of transects were established in the littoral area perpendicular to the shoreline. They were $1.2 \mathrm{~m}$ wide and 13-22 m long, depending on the width of the littoral zone. There were two transects in both the sparse and dense stands of T. angustifolia, of which one was fenced and the other was left open. The fence was made of $1 \mathrm{~m}$ wide, green LLDPE-coated diamond-mesh netting with a $0.02 \mathrm{~m}$ mesh size, which was attached to wooden poles hammered to a depth of $0.5 \mathrm{~m}$ in the solid bottom sediment. It extended from the bottom sediment to a height of $0.5-0.6 \mathrm{~m}$ above the water level. The experiment lasted from March 1 (i.e., before the start of the growing season) to July 31, 2015 (after the aboveground biomass achieved its seasonal maximum). At the end of the experiment, the transects were divided into 1-m long segments, in which the number of green shoots were counted.

\section{Density and activity of geese}

The counts of the greylag geese on the fishpond in the years 2002-2016 were obtained from the Nature Conservation Agency of the Czech Republic. The bird censuses were made from the ground using a standard approach every month. For the purpose of this study, the data were separated according to the annual cycle in the activity of the geese, i.e. spring migration (February-March), breeding (April-July) and autumn migration (August-November). Monthly mean counts and monthly maximum counts were calculated for each season within each year.

As the geese were often observed in the sparse stand of T. angustifolia, an infrared camera was installed there from August to November 2013 in order to record whether they were feeding on the plants. We used a SG-007 (ScoutGuard, USA) set to take 9 photographs in $30 \mathrm{~s}$ following activation of the motion sensor.

\section{Statistical analyses}

In order to determine the differences between the biotopes in terms of the chemical characteristics of the water and sediments, the following statistical hypothesis was set:
(H0) There are no differences between the biotopes in terms of the chemical characteristics of the water and sediments.

The data were assessed using one-way ANOVA followed with a Tukey post-hoc test. The data were tested for normality using a normal probability plot and for homogeneity of variance using the Levene test.

With regard to the potential harmful effect of the sediment on the growth characteristics of T. angustifolia in the mesocosm, the hypothesis tested was:

(H0) The sediment does not have a harmful effect on the plant growth characteristics. The effect was tested using hierarchical ANOVA, where the factor "substrate" was set superior to the "tub" factor.

In order to determine whether fencing protects T. angustifolia plants from damage in the enclosure experiment, the hypothesis tested was:

(H0) The shoot density is the same in the fenced transects as in the control (unfenced) transects, within each type of stand (dense or sparse).

The data were then evaluated using Chi-square tests.

The inter-annual trend in geese counts was tested using linear regression, applied to monthly means in a particular period of the geese annual cycle (i.e. spring migration, breeding and autumnal migration). the hypothesis tested was:

(H0) There was no inter-annual trend in the monthly mean counts. The same procedure was applied to monthly maxima.

All the statistical analyses were done using Statistica 12 (Statsoft, Inc., USA).

\section{Results}

\section{Extent and condition of the littoral vegetation}

The dominant plants in the littoral vegetation were Typha angustifolia (growing in depths of water of $0.3-0.4 \mathrm{~m}$, the minimum water level in summer), T. latifolia (in depths $0.1-0.2 \mathrm{~m}$ ) and Phragmites australis (forming a narrow belt along the dams) (Fig. 4). Other species of plants were scarce and made up less than $5 \%$ of the stands. The area covered by helophytes suitable for birds to nest in was $28,721 \mathrm{~m}^{2}$ and $9,457 \mathrm{~m}^{2}$ in 2004 and 2013, respectively, which corresponds to 48 and $16 \%$ of the total area of the fishpond and indicate that the area covered by helophytes decreased by $2 / 3 \mathrm{rds}$ in ten years. This decline was most pronounced in the south-eastern part of fishpond, where dense stands of T. angustifolia originally covered much of the area. 
This marked reduction was associated with the apparent die-back of the current stands of T. angustifolia. The shoot densities frequently decreased towards the waterward edge of the stands. At some sites, the whole stands were sparse, formed by isolated islets several meters apart. The smallest islets consisted of individual clumps with about 10-20 shoots, of which several were flowering. Shoots at the perimeters of clumps were often damaged by grazing (Fig. 5a) and there were no horizontal rhizomes growing from these clumps within a $10 \mathrm{~cm}$ upper layer of the solid sediment or apical rhizome buds protruding from the bottom of the fishpond near the clumps. Some clumps were uprooted (Fig. 5b). They occurred along the water edge of the littoral belt and throughout the stands in the south-eastern part of the fishpond. Although the clumps had green shoots, their belowground parts were severely damaged (Fig. 5c). In the south-eastern part of the fishpond, the belowground systems of the isolated clumps formed compact blocks about $0.5 \mathrm{~m}$ in diameter and 0.6 to $0.8 \mathrm{~m}$ in height. They had very weak or no connection with the bottom. Much of their surface was exposed to water and loose sediment.

No living rhizomes extended from them. Roots extending from the blocks were scarce, short and thick and often had necrotic tips. The blocks smelt of organic acids.

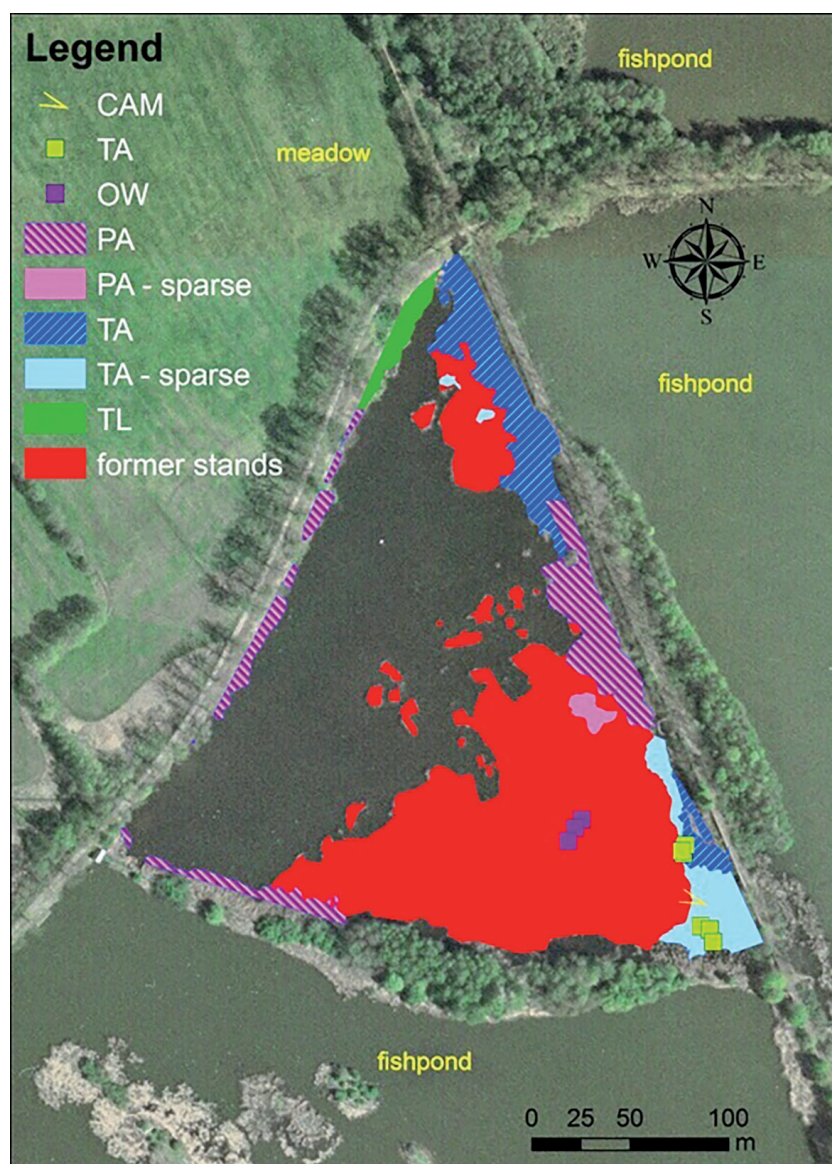

Fig. 4 Vegetation map of littoral stands of plants in 2013 plotted on the orthophoto map from 2004. CAM - camera, TA - stands of Typha angustifolia, TL - stands of T. latifolia, OW - open water. Squares indicate positions where water and sediments were sampled. Former stands disappeared between 2004 and 2013.

\section{Physico-chemical conditions in the littoral biotopes}

The nutrient contents in the photic zone (clear water column) were similar in the three littoral biotopes (dense, sparse and dead littoral stands of T. angustifolia, respectively) (Table 1).

Table 1 Nutrients in the photic zone, water and dry matter in the loose sediment and dry matter in the solid sediment in August 2013. TN - total nitrogen, TP - total phosphorus, LOI - organic matter content based on loss on ignition. The numbers are means for the water in the photic zone $(n=2)$ and mean \pm standard error for the sediments $(n=3)$. Significant differences within a row are given in bold and indicated by different small letters.

\begin{tabular}{|c|c|c|c|}
\hline \multirow[t]{2}{*}{ Parameter } & \multicolumn{3}{|c|}{ Biotope } \\
\hline & Dense stand & Sparse stand & Open water \\
\hline & \multicolumn{3}{|c|}{ Water in photic zone } \\
\hline $\mathrm{TN}\left(\mathrm{mg} \mathrm{l}^{-1}\right)$ & 2.29 & 2.29 & 2.18 \\
\hline $\mathrm{TP}\left(\mu \mathrm{gl}^{-1}\right)$ & 278 & 293 & 323 \\
\hline $\mathrm{K}\left(\mathrm{mg} \mathrm{l}^{-1}\right)$ & 7.4 & 7.5 & 7.4 \\
\hline $\mathrm{Ca}\left(\mathrm{mg} \mathrm{l}^{-1}\right)$ & 33.7 & 35.2 & 34.9 \\
\hline \multirow[t]{2}{*}{$M g\left(\mathrm{mg} \mathrm{l}^{-1}\right)$} & 6.3 & 6.6 & 6.5 \\
\hline & \multicolumn{3}{|c|}{ Water in loose sediment } \\
\hline TN $\left(\mathrm{mg} \mathrm{l}^{-1}\right)$ & $5.38 \pm 0.50$ a & $9.25 \pm 1.46 b$ & $3.41 \pm 0.21 \mathrm{a}$ \\
\hline $\mathrm{TP}\left(\mu \mathrm{gl}^{-1}\right)$ & $274 \pm 98{ }^{a}$ & $900 \pm 275^{b}$ & $143 \pm 29$ a \\
\hline $\mathrm{K}\left(\mathrm{mg} \mathrm{l}^{-1}\right)$ & $7.6 \pm 0.1$ & $9.4 \pm 0.8$ & $7.7 \pm 0.4$ \\
\hline $\mathrm{Ca}\left(\mathrm{mg} \mathrm{l}^{-1}\right)$ & $35.5 \pm 2.0$ & $42.3 \pm 2.5$ & $37.8 \pm 1.4$ \\
\hline$M g\left(\mathrm{mg} \mathrm{l}^{-1}\right)$ & $7.0 \pm 0.4$ & $8.5 \pm 0.5$ & $7.1 \pm 0.4$ \\
\hline \multirow[t]{2}{*}{$\mathrm{Fe}\left(\mathrm{mg} \mathrm{l}^{-1}\right)$} & $0.44 \pm 0.06^{a}$ & $0.19 \pm 0.01^{b}$ & $0.26 \pm 0.04 b$ \\
\hline & \multicolumn{3}{|c|}{ Dry matter in loose sediment } \\
\hline $\mathrm{TN}\left(\mathrm{mg} \mathrm{kg}^{-1}\right)$ & $13,691 \pm 2,800$ & $18,400 \pm 1,713$ & $17,851 \pm 953$ \\
\hline $\mathrm{TP}\left(\mathrm{mg} \mathrm{kg}^{-1}\right)$ & $858 \pm 67$ a & $1,381 \pm 152 b$ & $1,228 \pm 114 \mathrm{ab}$ \\
\hline $\mathrm{K}\left(\mathrm{mg} \mathrm{kg}^{-1}\right)$ & $351 \pm 47$ & $420 \pm 36$ & $456 \pm 70$ \\
\hline $\mathrm{Ca}\left(\mathrm{mg} \mathrm{kg}^{-1}\right)$ & $4,559 \pm 594^{a}$ & $6,902 \pm 707 a b$ & $7,503 \pm 301^{b}$ \\
\hline $\mathrm{Mg}\left(\mathrm{mg} \mathrm{kg}^{-1}\right)$ & $509 \pm 95$ & $746 \pm 82$ & $904 \pm 113$ \\
\hline \multirow[t]{2}{*}{ LOI (\%) } & $40.4 \pm 2.8$ ab & $30.3 \pm 2.1 \mathrm{a}$ & $48.5 \pm 3.6^{b}$ \\
\hline & \multicolumn{3}{|c|}{ Dry matter in solid sediment } \\
\hline $\mathrm{TN}\left(\mathrm{mg} \mathrm{kg}^{-1}\right)$ & $1,705 \pm 3$ & $3,055 \pm 1,228$ & $2,470 \pm 762$ \\
\hline $\mathrm{TP}\left(\mathrm{mg} \mathrm{kg}^{-1}\right)$ & $257 \pm 20$ & $412 \pm 167$ & $187 \pm 12$ \\
\hline $\mathrm{K}\left(\mathrm{mg} \mathrm{kg}^{-1}\right)$ & $96 \pm 6$ & $175 \pm 61$ & $87 \pm 23$ \\
\hline $\mathrm{Ca}\left(\mathrm{mg} \mathrm{kg}^{-1}\right)$ & $1,609 \pm 202$ & $3,025 \pm 1,494$ & $3,212 \pm 918$ \\
\hline $\mathrm{Mg}\left(\mathrm{mg} \mathrm{kg}^{-1}\right)$ & $217 \pm 13$ & $330 \pm 95$ & $259 \pm 56$ \\
\hline LOI (\%) & $12.2 \pm 2.0$ & $17.7 \pm 6.0$ & $6.0 \pm 1.3$ \\
\hline
\end{tabular}

Some differences between biotopes in nutrient content were recorded in the loose sediment. Its thickness was $0.30-0.40 \mathrm{~m}$ in both the dense and sparse stands (Table 2). It filled the space between the clumps, thus surrounds the plant root and rhizomes. The water in the loose sediment had higher contents of both total nitrogen and total phosphorus in sparse than in dense and dead stands (Table 1). In addition, the loose sediment in dense stands had a significantly lower dry matter content, and lower contents of total $\mathrm{P}$ and $\mathrm{Ca}$ than the sparse and dead stands. It had also lower contents of other nutrients (total nitrogen, $\mathrm{K}, \mathrm{Mg}$ ), but these differences were not 
significant (Table 1). We found no significant differences between biotopes in the nutrient contents in the dry matter of the solid sediment.

Table 2 Sediment characteristics of $T$. angustifolia biotopes. The redox potential was measured at the interface between the loose and the solid sediments. The numbers denote medians (minimum; maximum).

\begin{tabular}{lcc}
\hline Biotope & $\begin{array}{c}\text { Depth of loose sediment } \\
(\mathrm{cm})\end{array}$ & $\begin{array}{c}\text { Redox potential } \\
(\mathrm{mV})\end{array}$ \\
\hline Dense stand & $35(34 ; 38)$ & $30(-87 ; 332)$ \\
\hline Sparse stand & $36(30 ; 37)$ & $-13(-140 ; 10)$ \\
\hline Dead stand & $21(14 ; 26)$ & $-155(-195 ;-52)$ \\
\hline
\end{tabular}
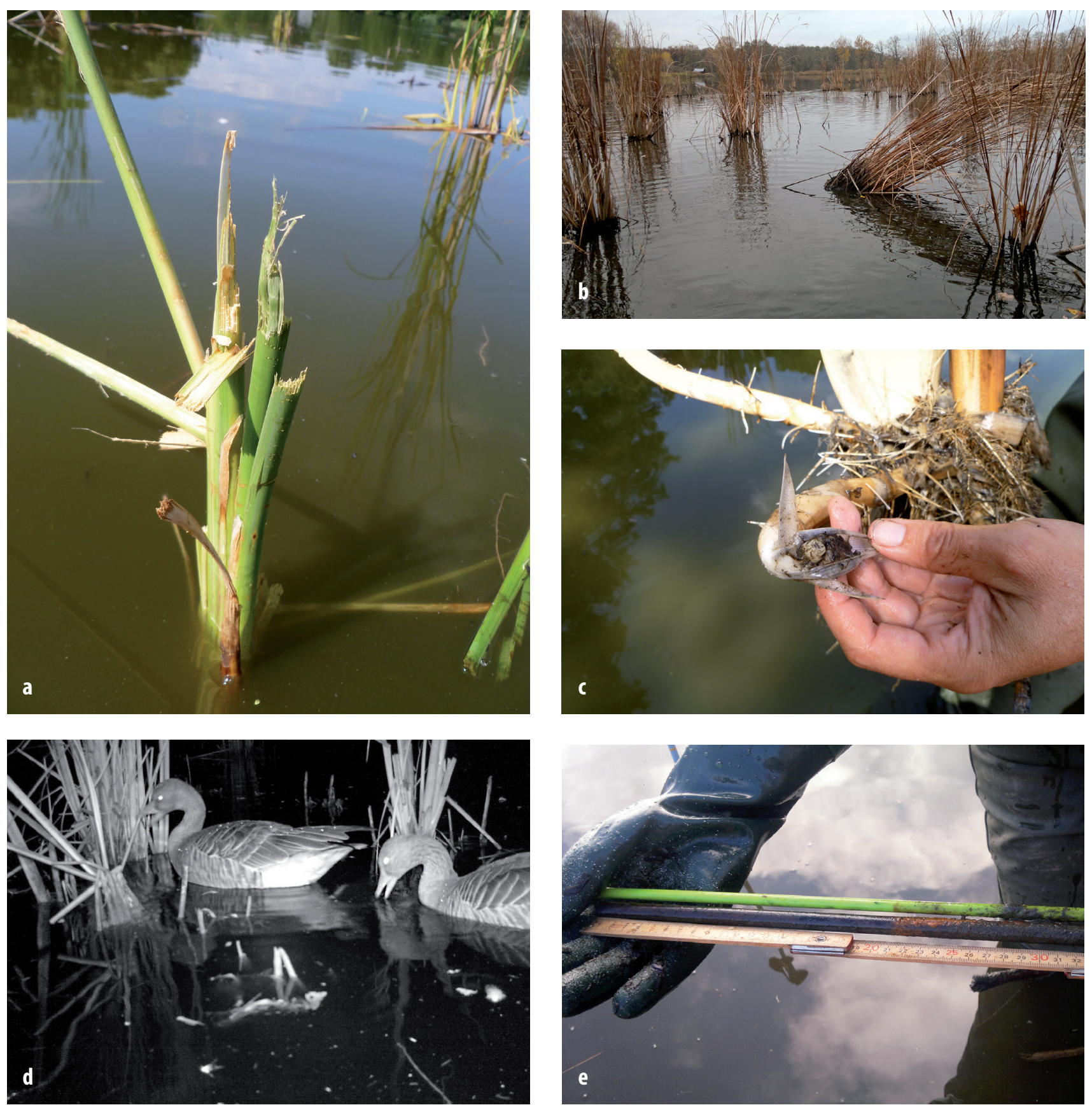

Fig. 5 Photographs of the condition of T. angustifolia biotopes; a - shoots damaged by grazing in a sparse stand; b - uprooted clumps in a sparse stand; $c$ - broken rhizome apex of an uprooted plant; $d$ - greylag geese grazing in a sparse stand (night photograph taken by camera); e - a green fibre-glass stick labelling a site and an iron stick indicating the redox conditions in water and sediments. The arrows indicate the interface between the oxidised and reduced zones on the sticks. 
Table 3 Growth characteristics of T. angustifolia plants grown in sand and fishpond sediment in a mesocosm. DW - biomass dry weight. Belowground biomass comprises the biomass of rhizomes and roots. Means \pm standard deviations, $n=12$. Statistically significant differences between the substrates are given in bold.

\begin{tabular}{|c|c|c|c|c|}
\hline \multirow[t]{2}{*}{ Growth characteristic } & \multicolumn{2}{|c|}{ Substrate } & \multirow[t]{2}{*}{$\mathrm{F}$} & \multirow[t]{2}{*}{$p$} \\
\hline & Sand & Sediment & & \\
\hline Total length of leaves $(\mathrm{cm})$ & $1374 \pm 551$ & $2297 \pm 613$ & 19.63 & $<0.001$ \\
\hline Final shoot DW (g) & $34.82 \pm 7.40$ & $52.62 \pm 15.08$ & 20.68 & $<0.001$ \\
\hline Final rhizome DW (g) & $43.82 \pm 14.91$ & $49.82 \pm 17.50$ & 0.79 & 0.384 \\
\hline Final root DW (g) & $15.09 \pm 3.57$ & $13.55 \pm 3.76$ & 0.97 & 0.336 \\
\hline Belowground / shoot ratio & $1.74 \pm 0.50$ & $1.29 \pm 0.59$ & 4.75 & 0.041 \\
\hline Rhizome / shoot ratio & $3.58 \pm 1.31$ & $3.13 \pm 1.14$ & 2.70 & 0.115 \\
\hline Root / shoot ratio & $0.39 \pm 0.13$ & $0.31 \pm 0.10$ & 29.92 & $<0.001$ \\
\hline
\end{tabular}

\section{Mesocosm}

The fishpond sediment differed from the sand in redox conditions as indicated by the colour of the iron sticks, which was reddish in the sand and dark grey in the sediment.

The type of substrate (fishpond sediment or sand enriched with mineral nutrients) had pronounced effects on plant growth. The aboveground parts of the plants grew generally better in the fishpond sediment. The plants had a significantly greater length of newly produced live leaves, and significantly greater shoot biomass at the end of the experiment than the plants cultivated in sand (Table 3 ).

No significant effects were recorded for either root or rhizome biomass or the ratio of rhizome: shoot biomass. Nevertheless, the ratios of belowground/shoot biomass and root/shoot biomass were significantly smaller in the fishpond sediment (Table 3), indicating a shift in biomass allocation from roots to shoots. No dead root tips or other symptoms of root injury were observed in either substrate.

\section{Enclosures}

In the fenced enclosures the shoot densities were significantly greater than in unfenced (control) areas in

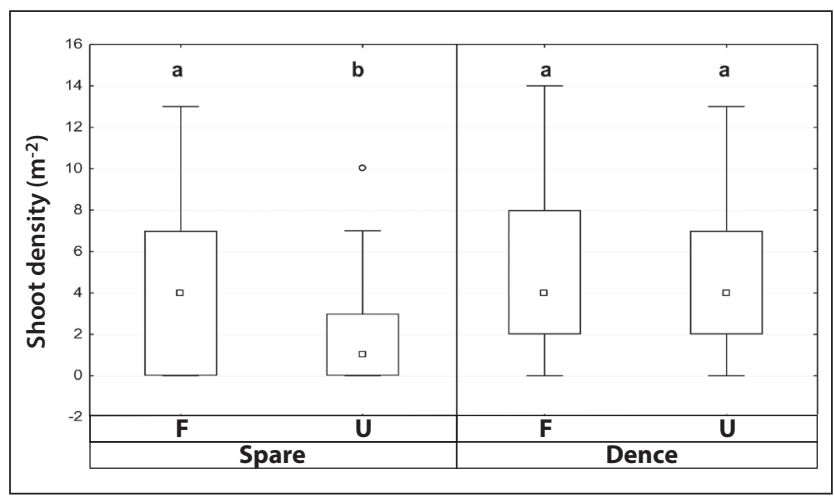

Fig. 6 Total number of shoots in fenced $(F)$ and unfenced $(U)$ areas in sparse and dense stands of T. angustifolia. The box plot shows medians (squares), quartiles (boxes), maximum and minimum values (whiskers) and an outlier (circle). sparse stands $\left(\chi^{2}=109\right.$, d.f. $=1, p<0.001$, Fig. 6). In dense stands, the shoot densities were similar in fenced and unfenced stands. They were also similar to those in fenced areas in sparse stands. In addition, grazing damage on shoots was recorded in the unfenced areas in sparse stands, but not dense stands.

\section{Geese and fish activity}

In 2013 damage to plants was frequently recorded, especially in sparse stands of T. angustifolia. As documented by photographs, this damage was done by geese (Fig. 5d).

Apart from one exception, the geese were recorded at the fishpond only when they were breeding. Their numbers increased considerably over the period of this study. While the seasonal maximum counts were $2-12$ in 2002-2010, 44 were recorded in 2012, which corresponds to more than seven individuals per hectare. The trends in the numbers of geese from 2001 to 2016 were highly significant in terms of both the monthly means and maximum counts during the breeding season (Fig. 7).

In addition to geese grazing on shoots, adult carp (about $2 \mathrm{~kg}$ ) were repeatedly observed shaking small isolated clumps of plants (up to $0.25 \mathrm{~m}^{2}$ ) in the sparse stand of T. angustifolia in 2012-2014.

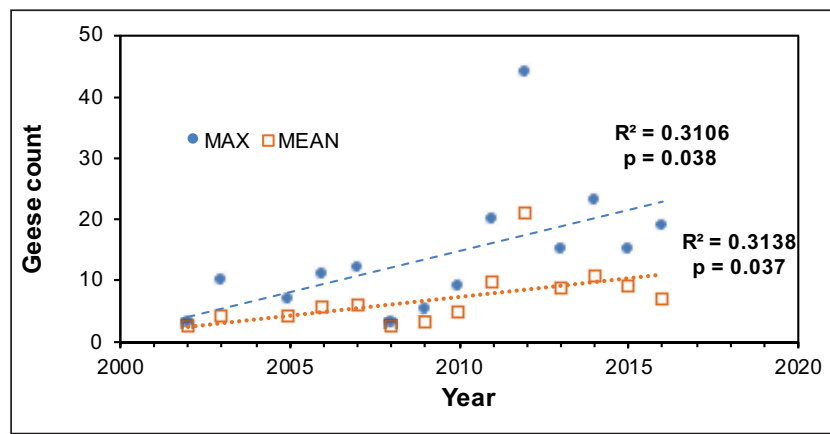

Fig. 7 Trends in numbers of greylag geese (Anser anser) on Bažina fishpond during the breeding period (March to July) from 2002 to 2016. MAX - monthly maximum numbers, MEAN - monthly mean numbers. Dotted lines indicate linear regressions. The data were provided by the Nature Conservation Agency of the Czech Republic. 


\section{Discussion}

\section{Role of abiotic factors}

The physico-chemical characteristics of water quality confirmed the extremely high trophic status of the fishpond (cf. Pechar 2000; Šimek et al. 2019). The same was true for both the water and dry matter of the loose sediment (cf. Čížková et al. 2001). The low redox potentials, recorded in the solid bottom sediment are also reported in other similar hypertrophic or eutrophic fishponds in the region (Čížková et al. 2001).

On the other hand, the dark layer containing the loose sediment, which formed in late spring as the temperature increased above $20^{\circ} \mathrm{C}$ (Fig. 1), is to the best of our knowledge not previously reported occurring in fishponds in central Europe. Although there is some oxygen in this layer, possibly a result of water mixing, the conditions are predominantly anaerobic based on iron stick measurements (Fig. 5e).

Of the environmental components investigated (i.e. fishpond water, water and dry matter in loose sediment and dry matter in the solid sediment) water and dry matter in the loose sediments differed in the biotypes. Higher contents of total nitrogen and total phosphorus were recorded in sparse, rather than dense stand (Table 1), which may indicate a high degree of eutrophication. Nevertheless, it is questionable whether these differences effect the plants because nutrient values were extremely high in all the biotopes. In addition, it is unlikely that high nutrient levels would have a deleterious effect per se. As has been documented for Phragmites australis, the decline of its stands at eutrophic sites is not due to nutrient levels but the secondary effect of eutrophication, i.e. toxic substances originating from the anaerobic decomposition of the organic matter present (Armstrong et al. 1996; van der Putten 1997; Čížková et al. 1999; Armstrong and Armstrong 2001). It seems reasonable to assume that the same mechanism would also hold for T. angustifolia.

Reducing conditions promote the formation of substances toxic to plants (e.g. Reddy and De Laune 2008; Lamers et al. 2012). One of them, iron in the reduced state $\left(\mathrm{Fe}^{\mathrm{II}}\right)$, might occur in both the loose and the solid sediments, as is indicated by the grey colour of the surface of iron sticks (Fig. 5e) and redox potential values below $+100 \mathrm{mV}$ (Table 2). Toxic effects or the reduced forms of iron are reported for other wild wetland plants (Lucassen et al. 2000; Li et al. 2017) and rice (Becker and Asch 2005). On the other hand, very low Fe contents (below $1 \mathrm{mg} \mathrm{l}^{-1}$ ) were recorded in the water in loose sediment in all three biotopes and, therefore, it is unlikely it would have had a toxic effect.

Although the fishpond sediment was reduced and therefore potentially toxic, it did not adversely affect the growth of the plants in the mesocosm (Table 3). On the contrary, the plants prospered even better in fishpond sediment than in the control substrate (sand enriched with the mineral nutrients). This might have been due to a more balanced nutrient supply in the organic fishpond sediment, which could not be fully simulated by adding inorganic fertilizer to the sand.

These results indicate that T. angustifolia is well adapted to anaerobic conditions. This is in accordance with the finding of Čížková et al. (1996) that it can grow in strongly reducing black mud in fishpond littoral zones. This is probably due to this plant having extraordinarily high numbers of spaces containing gas in both its shoots and roots (Seago et al. 2005; Schweingruber et al. 2020).

\section{Role of biotic factors}

The results of the enclosure experiment (Fig. 6) indicate that fencing can have a marked effect on shoot density in sparse stands. In contrast, the results indicate there was no grazing damage in dense stands because there were similar densities of plants in fenced and unfenced areas.

Generally, fish (Hroudová et al. 2010; Francová et al. 2019a) and/or water birds (Chaichana et al. 2011; Bakker et al. 2018) can destroy the littoral stands of plants when they are abundant. The design of the enclosures does not allow the separation the effects of fish and water birds. However, the effect of fish can be excluded because there was only fry in the fishpond in 2015. The T. angustifolia clumps were not damaged by fry because they are small $(10-20 \mathrm{~g}, 6-10 \mathrm{~cm})$ and feed on small zooplankton. It can, therefore, be concluded that the destruction of the littoral plants by geese was the sole cause of the decline in stands of littoral plants in 2015 and probably also in the other years when only fry was present in the fishpond. Increasing pressure on the littoral stands of plants by geese is supported by the four-fold increase in geese counts over the period of this study (Fig. 7). Moreover, photographs taken at night (Fig. 5d) revealed that geese graze T. angustifolia plants in late summer and autumn (August to October), when they aggregate prior to migration. At that time, their presence was not detected by the daytime censuses because they are then feeding in surrounding fields and are only present at the fishpond at night.

In addition to geese, some damage could have been caused by adult carp present in the fishpond in 2012-2014. Because of lack of large zooplankton in summer, carp feed on zoo benthos, which is present on root surfaces in greater densities than in the surrounding anaerobic mud as oxygen leaks from the roots (Hargeby et al. 1994; Ságová-Marečková and Květ 2002). While moving around the isolated clumps, the carp probably broke buds extending from the rhizomes (Fig. 5c) and thus prevented vegetative spreading. Compared with the solid mineral bottom, the loose organic sediment may facilitate the searching for food by fish on root surfaces in already damaged stands of plants. In addition, Boarman and Fuller (1981) and Weisner (1991) propose that littoral plants may be anchored less well in soft sediments than in solid ones, which makes them 
more vulnerable to disturbance. Insufficient anchorage of the plants would ultimately lead to uprooting, such as observed in this study (Fig. 5b).

It is interesting to note that fencing only protected sparse stands (cf. Fig. 6). This is probably due to the fact that geese can easily move around in the gaps between the clumps in sparse stands. On the other hand, they only damaged dense stands on their waterward side. This was observed repeatedly, but the experiments were not designed to detect it.

\section{Possible management measures}

Overstocking with cyprinid fish has commonly been seen as a constraint on fishponds in terms of supporting populations of water birds (Broyer and Calenge 2010; Broyer and Curtet 2012). This study draws attention to an additional conservation dilemma, i.e. how to preserve littoral stands plants that are being damaged by increasing densities of greylag geese (Fig. 7). Herbivorous birds such as geese do not compete with fish for food because they feed in surrounding crops and grasslands. They are also legally protected in nature reserves. As geese numbers increase, they increasingly destroy littoral stands of plants, where species of rare water birds nest. This may increase in importance in the near future owing to changes in migratory behaviour in response to ongoing climate change (Podhrázský et al. 2017).

As Bakker et al. (2018) point out, the conservation of both the littoral stands of plants and high geese numbers appears to be impossible. There are two possible solutions: (1) negative effects of geese can be limited by the regulation of their population size. Lethal scaring (i.e. shooting some geese to scare other members of the flocks) has been reported as a successful measure to prevent geese damage in agricultural crops (Månsson 2017). This measure may be worth considering for preventing the destruction of littoral stands of plants in late summer (i.e., from the beginning of August), after the fledging of the young of the protected species of birds and the geese gather in nature reserves in order to escape from hunting. Nevertheless, this may be hard to achieve in a nature reserve because local inhabitants and tourists are likely to protest. Using lasers to scare geese has been used, but so far with limited success (Clausen et al. 2019).

An alternative to scaring geese may be the regeneration of the littoral stands of plants by a partial lowering of the water level once in several years, which would expose the littoral zone to air, which promotes both the vegetative and generative reproduction of the plants (Rea 1996; Hroudová et al. 2010). It also prevents geese from feeding on the young plants provided the water table remains low till autumn, when the shoots are tall enough and no longer an attractive food for geese. During the draw-down, another fishpond in the vicinity should be filled with water in order to provide nesting habitats for the protected species of water birds.

\section{Conclusions}

In a hypertrophic fishpond, which is also a nature reserve for rare species of water birds, the area suitable for nesting decreased by $2 / 3$ rds over a period of 10 years. Although chemical analyses of water and sediments confirmed hypertrophic conditions, the results of a mesocosm study indicated that sediment quality did not negatively affect the quality of the plants. In contrast, field enclosures revealed a significant biotic effect, which was attributed to shoot grazing by large numbers of geese. Damage to the belowground parts of plants, recorded in isolated clumps in disintegrated stands, was ascribed to large carp.

This study revealed that, although fish production was strictly limited in the fishpond because the conservation of water birds was a management priority, damage caused by fish could not be fully prevented. More importantly, it reveals a conservation dilemma in that the large numbers of geese destroyed littoral stands of plants, which resulted in the loss of nesting sites for other species of water birds.

\section{Acknowledgements}

This study was financially supported by project No. 081/2016/Z of the Grant Agency of the University of South Bohemia, by a long-term research development project no. RVO 67985939 of the Academy of Sciences of the Czech Republic and by contract No. KUJCK 43725/2014 OZZL of the Regional Office of South Bohemia.

The data on fishpond management and fish stocks were provided by P. Oberreiter, head of fisheries management of the Forests and Fishponds of the City of České Budějovice, Ltd. The data on geese counts were provided by T. Bodnár and J. Pykal of the Nature Conservation Agency of the Czech Republic.

We thank P. Stehlík (Regional Office of South Bohemia) and J. Staněk (Fishponds and Forests of the City of České Budějovice, Ltd.) for valuable feedback. We also thank our colleagues P. Musil, I. Šetlíková and L. Šimek for helpful discussions, P. Rost for advice on statistical analyses and S. Svidenská for translation of the manuscript.

\section{REFERENCES}

Albrecht J (ed) (2003) Českobudějovicko. Protected areas of the Czech Republic VIII. AOPK ČR, Praha, EkoCentrum, Brno. [In Czech].

Armstrong J, Armstrong W (2001) An overview of the effects of phytotoxins on Phragmites australis in relation to die-back. Aquat Bot 69: 251-268.

Armstrong J, Armstrong W, Zenbin W, Afreen-Zobayed F (1996) A role of phytotoxins in the Phragmites die-back syndrome. Folia Geobot 31: 127-142. 
Bakker ES, Veen C, ter Heerdt G, Huig N, Sarneel J (2018) High grazing pressure of geese threatens conservation and restoration of reed belts. Front Plant Sci 9: 1649.

Baxa M, Šulcová J, Kröpfelová L, Pokorný J, Potužák J (2019) The quality of sediment in shallow water bodies - Long-term screening of sediment in Czech Republic. A new perspective of nutrients and organic matter recycling in agricultural landscapes. Ecol Eng 127: 151-159.

Becker M, Asch F (2005) Iron toxicity in rice - conditions and management concepts. J Plant Nutr Soil Sci 168: 558-573.

Bird Life International (2001): Important Bird Areas and potential Ramsar Sites in Europe. BirdLife International, Wageningen, the Netherlands. https://www.birdlife.org/sites/default/files /attachments/ibas_ramsar_europe_0_0.pdf

Bíró P (1995) Management of pond ecosystems and trophic webs. Aquaculture 129: 373-386.

Boorman LA, Fuller RM (1981) The changing status of reedswamp in the Norfolk Broads. J Appl Ecol 18: 241-269.

Broyer J, Calenge C (2010) Influence of fish-farming management on duck breeding in French fish pond systems. Hydrobiologia 637: 173-185.

Broyer J, Curtet L (2012) Biodiversity and fish farming intensification in French fishpond systems. Hydrobiologia 694: 205-218.

Chaichana R, Leah R, Moss B (2011) Seasonal impact of waterfowl on communities of macrophytes in a shallow lake. Aquat Bot 95: 39-44.

Č́žžková H, Brix H, Kopecký J, Lukavská J (1999) Organic acids in the sediments of wetlands dominated by Phragmites australis: evidence of phytotoxic concentrations. Aquat Bot 64: 303-315.

Čížková H, Pechar L, Husák Š, Květ J, Bauer V, Radová J, Edwards K (2001) Chemical characteristics of soils and pore waters of three wetland sites dominated by Phragmites australis: relation to vegetation composition and reed performance. Aquat Bot 69: 235-249.

Čížková H, Strand JA, Lukavská J (1996) Factors associated with reed decline in a eutrophic fishpond, Rožmberk (South Bohemia, Czech Republic). Folia Geobot 31: 73-84.

Clausen KK, Marcussen LK, Knudsen N, Balsby TJ, Madsen J (2019) Effectiveness of lasers to reduce goose grazing on agricultural grassland. Wildlife Biol 1: 1-8.

Crivelli AJ (1983). The destruction of aquatic vegetation by carp. Hydrobiologia 106: 37-41.

Flis A, Gwiazda R (2018) Diet and feeding of nestling Little Bitterns Ixobrychus minutus at fishponds: testing a new method for studying a difficult-to-monitor species. Bird Study 65: 257-260.

Francová K, Šumberová K, Janauer GA, Adámek Z (2019a). Effects of fish farming on macrophytes in temperate carp ponds. Aquac Int 27: 413-436.

Francová K, Šumberová K, Kučerová A, Čtvrtlíková M, Šorf M, Borovec J, Drozd B, Janauer GA, Vrba J (2019b). Macrophyte assemblages in fishponds under different fish farming management. Aquat Bot 159: 103131.

Friis EP, Anderson JET, Madsen LL, Bonander N, Møller P, Ulstrup J (1998) Dynamics of Pseudomonas aeruginosa azurin and its Cys3Ser mutant at single-crystal gold surfaces investigated by cyclic voltammetry and atomic force microscopy Electrochim Acta 43: 1114-1122.

Gergely Z, Mészáros LA, Szabad J, Székely T (2009) Old nests are cues for suitable breeding sites in the Eurasian penduline tit Remiz pendulinus. J Avian Bio 40: 2-6.

Hargeby A, Andersson G, Blindow I, Johansson S (1994) Trophic web structure in a shallow eutrophic lake during a dominance shift from phytoplankton to submerged macrophytes. Hydrobiologia 279: 83-90.
Hejný S, Hroudová Z, Květ J (2002) Fishpond vegetation: an historical view. In: Květ J, Jeník J, Soukupová L (eds) Freshwater wetlands and their sustainable future. A case study of Třeboň Basin Biosphere Reserve, Czech Republic. UNESCO, Paris and CRC Press, Boca Raton, pp 63-95.

Hroudová Z, Kloubec B, Zákravský P (2010) Will the reed stands regenerate in the State Nature Reserve Velký a Malý Tisý? Ochrana př́rody 3: 12-15. [In Czech with English sum.].

IUCN (1997) Fishing for a living: the ecology and economics of fishponds in Central Europe. IUCN, Switzerland.

Janda J, Ševčík J (2002) Avifauna of the Třeboň fishponds and new wetlands. In: Květ J, Jeník J, Soukupová L (eds) Freshwater wetlands and their sustainable future. A case study of Třeboň Basin Biosphere Reserve, Czech Republic. UNESCO, Paris, and CRC Press, Boca Raton, pp 475-480.

Kestemont P (1995) Different systems of carp production and their impacts on the environment. Aquaculture 129: 347-372.

Kopáček J, Hejzlar J (1995) Semi-micro determination of total phosphorus in soils, sediments, and organic materials: A simplified perchloric acid digestion procedure. Commun Soil Sci Plan 26: 1935-1946.

Lamers LPM, van Diggelen JMH, Op den Camp HJM, Visser EJW, Lucassen ECHET, Vile MA, Jetten MSM, Smolders AJP, Roelofs JGM (2012) Microbial transformations of nitrogen, sulphur, and iron dictate vegetation composition in wetlands: a review. Front Microbiol 3: 1-12.

Li WC, Deng H, Wong MH (2017) Effects of Fe plaque and organic acids on metal uptake by wetland plants under drained and waterlogged conditions. Environ Pollut 231: 732-741.

Lucassen ECHET, Smolders AJP, Roelofs JGM (2000) Increased groundwater levels cause iron toxicity in Glyceria fluitans (L.). Aquat Bot 66: 321-327.

Månsson J (2017) Lethal scaring - Behavioral and short-term numerical response of greylag goose Anser anser. Crop Protection 96: 258-264.

Miklín J, Macháček P (2016) Birds of Lednické rybníky Fishponds (Czech Republic). J Maps 12: 239-248.

Mitsch WJ, Gosselink JG (2015) Wetlands. 5th edition. Wiley, Hoboken.

Nieoczym M (2010) The importance of fishponds to the preservation of avian biodiversity in agricultural landscape. Teka Kom. Ochr. Kszt. Środ. Przyr. - OL PAN 7: 290-296.

Ostendorp W (1989) 'Die-back' of reeds in Europe - a critical review of literature. Aquat Bot 35: 5-26.

Pechar L (2000) Impacts of long-term changes in fishery management on the trophic level water quality in Czech fish ponds. Fisheries Manag Ecol 7: 23-31.

Podhrázský M, Musil P, Musilová Z, Zouhar J, Adam M, Závora J, Hudec K (2017) Central European Greylag Geese Anser anser show a shortening of migration distance and earlier spring arrival over 60 years. Ibis 159: 352-365.

Polak M (2007) Nest-site selection and nest predation in the Great Bittern Botaurus stellaris population in eastern Poland. Ardea 95: 31-38.

Potužák J, Hůda J, Pechar L (2007) Changes in fish production effectivity in eutrophic fishponds - impact of zooplankton structure. Aquacult Int 15: 201-210.

Rea N (1996) Water levels and Phragmites: decline from lack of regeneration or dieback from shoot death. Folia Geobot 31: 85-90.

Reddy KR, De Laune RD (2008) Biogeochemistry of Wetlands. CRC Press, Boca Raton.

Ságová-Marečková M, Květ J (2002) Impact of oxygen released by the roots of aquatic macrophytes on composition and distribu- 
tion of benthic macroinvertebrates in a mesocosm experiment. Arch Hydrobiol 155: 567-584.

Schlumberger O, Girard P (2013) Mémento de pisciculture d’étang: 5e édition. Quæ, Versailles.

Schweingruber FH, Kučerová A, Adamec L, Doležal J (2020) Anatomic atlas of aquatic and wetland plant stems. Springer.

Seago Jr JL, Marsh LC, Stevens KJ, Soukup A, Votrubová O, Enstone DE (2005) A re-examination of the root cortex in wetland flowering plants with respect to aerenchyma. Ann Bot 96: 565-579.

Šimek K, Grujčić V, Nedoma J, Jezberová J, Šorf M, Matoušů A, Pechar L, Posch T, Bruni EP, Vrba J (2019) Microbial food webs in hypertrophic fishponds: Omnivorous ciliate taxa are major protistan bacterivores. Limnol Oceanogr 64: 2295-2309.

Švažas S, Stanevičius V (1998) Waterfowl of the large fish pond systems in Lithuania. Acta Zool Lit 8: 69-84. van der Putten WH (1997) Die-back of Phragmites australis in European wetlands: an overview of the European research programme on reed die-back and progression (1993-1994). Aquat Bot 59: 263-275.

Weber MJ, Brown ML (2009) Effects of common carp on aquatic ecosystems 80 years after "carp as a dominant": ecological insights for fisheries management. Rev Fish Sci Aquac 17: 524-537.

Weisner SEB (1991) Within-lake patterns in depth penetration of emergent vegetation. Freshwater Biol 26: 133-142.

Zbíral J (1995) Soil analysis I. Unified working procedures. SKZÚZ Brno. [In Czech].

Zbíral J, Němec P (2002) Comparison of Mehlich 2, Mehlich 3, CAL, Egner, Olsen, and $0.01 \mathrm{M} \mathrm{CaCl}_{2}$ extractants for determination of phosphorus in soils. Commun Soil Sci Plant Anal 33: 3405-3417. 